\title{
Kampung Eduwisata Hanjeli di Desa Waluran Mandiri Kabupaten Sukabumi
}

\author{
Iwan Rizal Setiawan ${ }^{1}$, Indra Griha Tofik Isa ${ }^{1}$, Siska Hestiana ${ }^{2}$, Ashrul Tsani ${ }^{3}$ \\ ${ }^{1}$ Departemen Teknik Informatika Fakultas Sains dan Teknologi, ${ }^{2}$ Departemen Sastra Inggris Fakultas IImu Administrasi \\ dan Humaniora, ${ }^{3}$ Departemen Agribisnis Fakultas Pertanian, Universitas Muhammadiyah Sukabumi \\ Jl. R. Syamsudin, S.H. No. 50, Sukabumi, 43113, Indonesia
}

ARTICLE INFO:

Received: 2020-07-09

Revised: 2020-09-20

Accepted: 2020-10-28

Keywords:

Community develop-

ment; Educational;

Edutourism village;

Hanjeli

\section{ABSTRACT}

Land use of Waluran Mandiri Village, which consists of agricultural land and rice fields, has the potential to increase the economy of the people in the area. However, this was not matched by the custom of local people who preferred to be gold miners, known as "Gurandil". Some of the commodities that can be developed in this area are Hanjeli beans. The purpose of this activity is to involve the community in developing the potential of hanjeli beans which are packaged in the Hanjeli edutourism village. The stages carried out in this activity were the initial workshop, community counseling, the formation of a group discussion forum, the revitalization of agricultural land, the making of a blueprint for the eduwisata Hanjeli edutourism village, and the final workshop. The final result of this activity is a blueprint of Hanjeli edutourism village which consists of budget design, educational spots, educational layouts (layout and spatial layout), the various arts involved and consolidation of the residents' land used.

(c) 2020 Published by University of Merdeka Malang. This is an open access article distributed under the CC BY-SA 4.0 license (https://creativecommons.org/licenses/by-sa/4.0/)

How to cite: Setiawan, I. R., Isa, I. G. T., Hestiana, S., \& Tsani, A. (2020). Kampung Eduwisata Hanjeli di Desa Waluran Mandiri Kabupaten Sukabumi. Abdimas: Jurnal Pengabdian Masyarakat Universitas Merdeka Malang, 5(3), 300-311. https://doi.org/10.26905/abdimas.v5i3.4382

\section{PENDAHULUAN}

Desa Waluran Mandiri merupakan bagian terluas dari wilayah Kecamatan Waluran yang memiliki luas $2.114 \mathrm{Ha}$ terdiri dari lahan pertanian dan persawahan sebanyak $2.024 \mathrm{Ha}$, hal ini menunjukan luas sebanyak 95\% merupakan lahan pertanian dan persawahan (BPS, 2016). Sehingga rata-rata penduduk di Desa Waluran Mandiri berprofesi sebagai petani dengan beberapa hasil bumi pertanian utama, antara lain beras putih, beras merah, dan kacang hanjeli. Kontur tanah yang terdapat di Desa Waluran Mandiri merupakan wilayah perbukitan, dimana sekitar $45 \%$ berupa tanah lereng. Penduduk daerah setempat memanfaatkan tanah lereng tersebut dengan menanam kacang Hanjeli. Dari tahun ke tahun produktivitas produksi kacang Hanjeli mengalami penurunan, salah satu faktor diantaranya adalah adanya kebiasaan 


\section{Kampung Eduwisata Hanjeli di Desa Waluran Mandiri Kabupaten Sukabumi}

Iwan Rizal Setiawan, Indra Griha Tofik Isa, Siska Hestiana, Ashrul Tsani

masyarakat Desa Waluran Mandiri yang sudah berjalan sejak dieksploitasinya tambang emas pada tahun 2000-an, yakni sebagai penambang emas liar atau dalam istilah setempat disebut "Gurandil". Secara ekonomi usaha penambangan emas liar dengan memanfaatkan lahan hutan dan perkebunan memberikan keuntungan, akan tetapi dalam pengelolaannya dilakukan secara tradisional serta tanpa ada pengaturan dan arahan yang jelas dari pihak terkait, maka dampak dari usaha tersebut dapat menjadi bencana pada masa yang akan datang. Dampak yang jelas terlihat adalah dengan berubahnya pola pikir masyarakat untuk mendapatkan keuntungan dengan mengorbankan keselamatan, lingkungan serta sumber daya jangka panjang. Hal ini dikarenakan lahan yang sebelumnya dapat dijadikan sebagai modal kehidupan jangka panjang beralih fungsi menjadi lubang-lubang tempat penggalian batu-batu mineral yang diprediksi mengandung emas (Gilang, 2018).

Masalah terparah dengan adanya penambang liar ini adalah tertimbunnya penambang yang mengakibatkan korban jiwa, bahwa korban tertimbun tanah sedalam 3 sampai 4 meter, karena kondisi tanah yang labil dan dipastikan lokasi itu ilegal (Alamsyah, 2016).

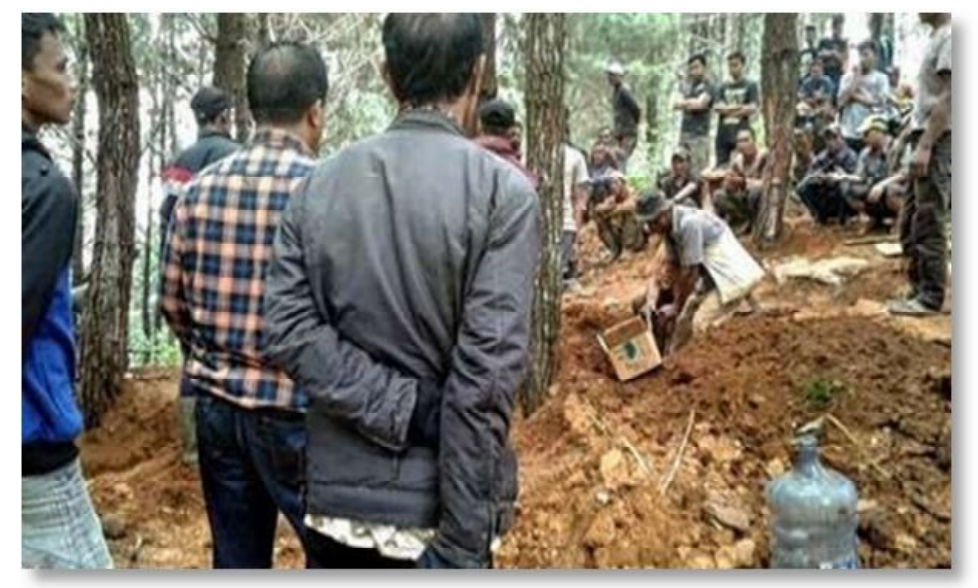

Gambar 1. Kondisi lahan tambang tempat korban jiwa penambang ilegal

Dampak lain selain masalah kesehatan adalah adanya perilaku masyarakat yang cenderung ingin mendapatkan keuntungan dalam waktu singkat, sehingga keadaan ini memaksa para istri untuk membantu suami mereka dalam proses pemecahan batu mineral yang diprediksi mengandung emas tersebut. Ketika para istri membantu suami mereka, maka mereka terpaksa meninggalkan anak anak mereka dan ini menimbulkan masalah baru dimana pengawasan serta pengasuhan mengalami pergeseran. Hal ini dikhawatirkan akan menimbulkan dampak yang lebih buruk, seperti degradasi moral generasi berikutnya, sehingga harus ada langkah nyata dalam menangani kekhawatiran tersebut di atas.

Menurut penuturan masyarakat Desa Waluran Mandiri, pada beberapa dekade sebelumnya Desa Waluran Mandiri adalah desa penghasil kacang hanjeli. Namun dikarenakan adanya perubahan cara pandang masyarakat yang lebih memilih jalan sebagai pencari emas, maka lahan hanjeli yang semula dijadikan sebagai mata pencaharian, lambat laun ditinggalkan dan lahan tersebut hanya menjadi lahan tidur yang tidak produktif. Beberapa tahun kemudian tanah tersebut dikhawatirkan akan menimbulkan masalah keamanan dikarenakan bahaya akan erosi, mengingat beberapa lahan berada di lereng bukit dan lambat laun dapat mengakibatkan longsor. Melalui Program Pengabdian Masyarakat ini akan 
ABDIMAS: Jurnal Pengabdian Masyarakat Universitas Merdeka Malang Volume 5, No 3, November 2020: 300-311

diupayakan untuk mengubah cara pandang masyarakat terutama tentang kondisi lingkungan yang akan memberikan dampak kurang baik dalam waktu jangka panjang. Potensi Kacang hanjeli yang ada di Desa Waluran Mandiri belum digarap secara maksimal oleh warga maupun kelompok tani (poktan) desa tersebut yang bernama Poktan Wanasari. Padahal kacang hanjeli memiliki nilai gizi yang tinggi terkandung di dalamnya, dan termasuk jenis kacang yang memiliki tingkat protein, Ca dan vitamin B1 lebih tinggi bila dibandingkan dengan beras, jagung dan sorgum (Wahyudin et al., 2017). Kacang Hanjeli sebenarnya bukanlah termasuk tanaman kacang-kacangan, akan tetapi masuk pada jenis serealia dengan nama latin Coix lacryma, namun di wilayah Indonesia khususnya di Jawa Barat, penyebutan kacang terhadap hanjeli telah diberikan secara turun temurun, selain itu kelebihan dari tanaman ini adalah karakteristik tanaman yang tahan terhadap stressing air dan dapat hidup pada lahan dengan unsur hara yang minimal, hal ini sangat cocok dengan lingkungan yang ada di Desa Waluran Mandiri.
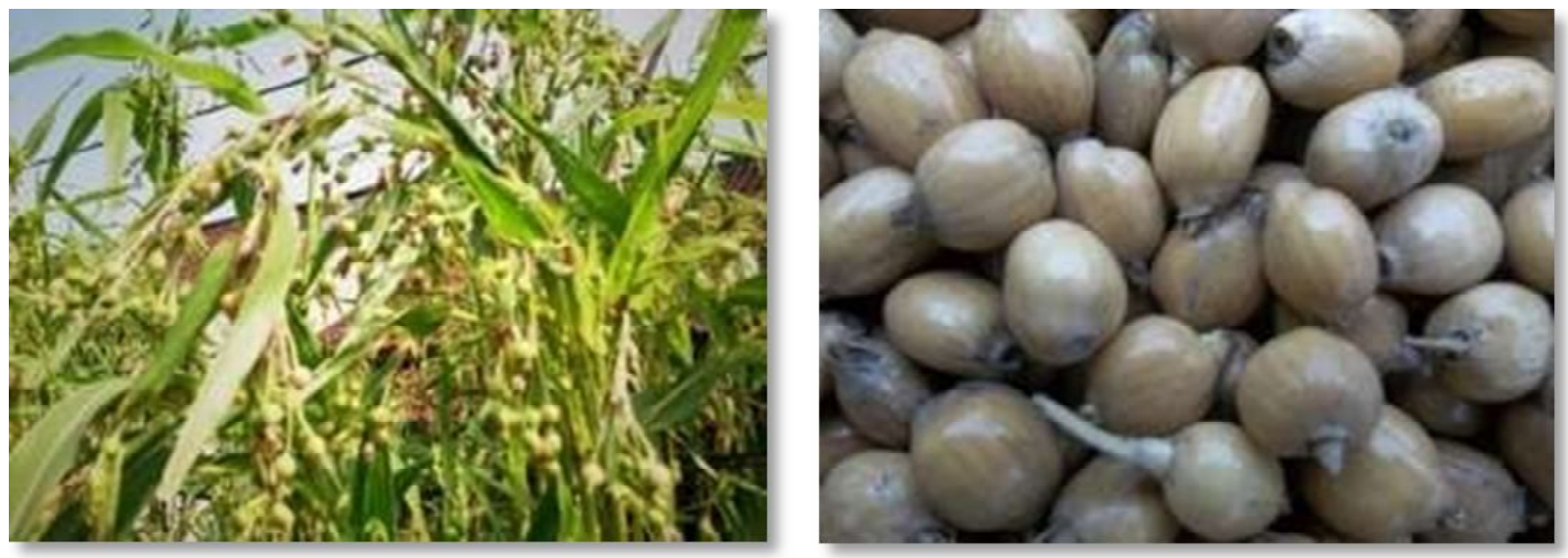

Gambar 2. Tumbuhan hanjeli (kiri) dan biji hanjeli (kanan)

Disamping potensi kacang hanjeli, Desa Waluran Mandiri memiliki ragam kesenian yang dikemas dalam sanggar seni Dangiang Sari. Kata Dangiangsari yang dipakai terdiri dari asal kata Dangiang artinya mempunyai daya tarik tersendiri dan Sari artinya rasa yang menempel pada kata Dangiang. Dangiangsari berdiri pada tahun 2011 di kecamatan Waluran (Isa et al., 2019)

Berdasarkan paparan tentang perilaku masyarakat Desa Waluran Mandiri, banyak permasalahan yang timbul, baik dari masalah lingkungan maupun sosial yang berkaitan dengan pola hidup masyarakat serta perubahan ritme kehidupan dari masyarakat agraris menjadi masyarakat pekerja yang menghabiskan waktu hampir 12 jam dalam sehari. Dampak dari adanya perubahan pola hidup masyarakat diantaranya: perhatian dan pengawasan terhadap anak menjadi berkurang, lahan banyak terbengkalai, lingkungan tercemar dan banyak galian liar, generasi muda mulai melupakan tata cara bertani khususnya kacang hanjeli, dan kepedulian terhadap kelangsungan hidup bermasyarakat mulai berkurang.

Sebagai alternatif dalam mereduksi permasalahan sosial kemasyarakatan tersebut salah satunya adalah dengan melakukan pemberdayaan masyarakat melalui pembentukan kampung wisata (Solikhah \& Fatimah, 2020; Dharmadiatmika, 2019; Susanti, 2018; Sudjatnika, 2017). Seperti yang diuraikan sebelumnya, bahwa Desa Waluran Mandiri memiliki beragam potensi yang meliputi: potensi pertanian berupa kacang hanjeli, potensi budaya, potensi kuliner dengan berbahan dasar kacang hanjeli, potensi alam dan demografi 


\section{Kampung Eduwisata Hanjeli di Desa Waluran Mandiri Kabupaten Sukabumi}

Iwan Rizal Setiawan, Indra Griha Tofik Isa, Siska Hestiana, Ashrul Tsani

maupun potensi SDM dan kearifan lokal sebagai pendukung dalam pemberdayaan masyarakat (Azis, 2017; Pramudito, 2017; Madiasworo, 2009). Sehingga hal yang dapat dilakukan adalah dengan membentuk kampung eduwisata hanjeli sebagai upaya pemberdayaan masyarakat di Desa Waluran Mandiri

\section{METODE}

Metode pelaksanaan dalam kegiatan terdapat dalam gambar 3 di bawah ini:

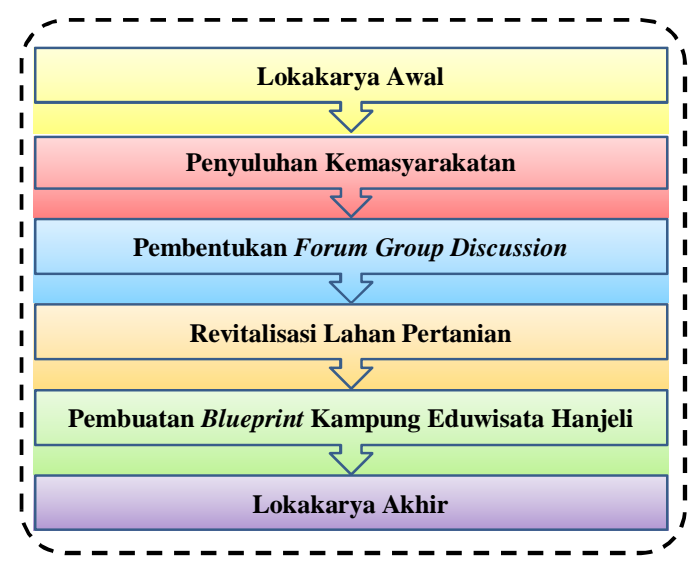

Gambar 3. Metode pelaksanaan kegiatan

\section{Lokakarya Awal}

Pada tahapan ini akan dilakukan paparan awal mengenai program kegiatan yang akan dilaksanakan. Dalam pelaksanaannya melibatkan warga Desa Waluran Mandiri, Aparatur Desa dan Kecamatan, Karang Taruna, tokoh masyarakat serta ibu PKK yang ada di Desa Waluran Mandiri. Pelaksanaan Lokakarya awal akan dilaksanakan di Kecamatan Waluran.

\section{Penyuluhan Kemasyarakatan}

Penyuluhan dilakukan dalam program kemitraan Desa Waluran Mandiri dengan melibatkan unsur masyarakat yang tergabung dalam kelompok tani dan komunitas wisata, dengan agenda untuk menyampaikan maksud dan tujuan Pengabdian Masyarakat dari kampus berdasarkan program dari Kementerian. Keterlibatan masyarakat dalam proses penyuluhan dimaksudkan untuk memberikan arahan sekaligus memberikan pembelajaran tentang konsep eduwisata beserta langkah dan persiapan yang perlu dilakukan. Proses penyuluhan dilakukan secara berjenjang berdasarkan urutan kebutuhan dalam pelaksanaan program pengabdian kepada masyarakat. Cara penyampaian penyuluhan dilakukan dengan beberapa cara.

\section{Ceramah}

Metode ini dilakukan dengan cara memberikan arahan dan pencerahan terhadap rencana yang akan dikerjakan berdasarkan kondisi yang berlaku di wilayah Desa Waluran Mandiri. Adapun ceramah dilakukan oleh Tim Pengabdian dengan bekerjasama dengan komunitas dan kelompok yang berkepentingan 
ABDIMAS: Jurnal Pengabdian Masyarakat Universitas Merdeka Malang

Volume 5, No 3, November 2020: 300-311

dengan program kemitraan desa. Ceramah dilakukan di tempat berkumpulnya banyak warga diantaranya: (1) Tempat ibadah (masjid); (2) Balai desa; (3) Posyandu; (4) Sekretariat komunitas.

\section{Diskusi}

Metode diskusi dilakukan setelah mendapat tanggapan positif dari masyarakat tentang programprogram yang akan dilakukan dan masyarakat diharapkan dengan sukarela dapat memberikan kesempatan untuk berkumpul dan membahas program sesuai dengan ketertarikan masyarakat terhadap program maupun bagian program yang saling mendukung, sehingga setiap program dengan berbagai permasalahanya diharapkan mendapat saran atau masukan untuk membentuk rencana kerja seperti terlihat pada Gambar 4 sehingga rencana kerja merupakan rancangan program dengan masukan dari masyarakat untuk dilaksanakan berdasarkan kesepakatan bersama antara tim pengusul dengan warga Desa Waluran Mandiri.

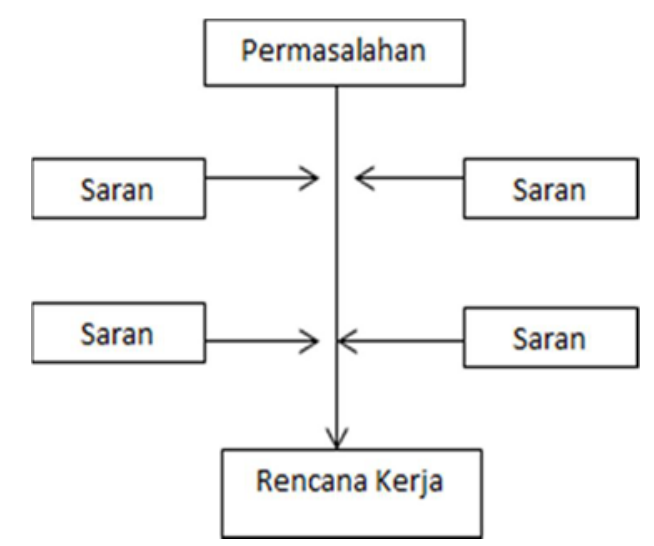

Gambar 4. Langkah diskusi menuju rencana kerja

\section{Demo Program}

Pada pelaksanaan demo program tentang kampung eduwisata hanjeli yang dicanangkan adalah dengan memperlihatkan beberapa pelaksanaan dari program tersebut dalam bentuk peragaan atau pemaparan dalam proses persiapan ataupun kegiatan pelaksanaan. Contoh demo yang sudah dipaketkan dalam kegiatan adalah pemaparan pengolahan kacang hanjeli dari proses tanam yang baik, pemeliharaan dan proses panen serta pasca panen dalam bentuk pengolahan berbagai panganan makanan terbuat dari bahan dasar hanjeli, adapun demo dilakukan dengan cara sebagai berikut: (1) Memberikan contoh peragaan proses; (2) Memberikan contoh hasil dari rencana program; (3) Memberikan gambar proses pelaksanaan program; (4) Memberikan video atau film durasi pendek gambaran pelaksanaan kegiatan.

\section{Pembentukan Forum Group Discussion}

Dalam pembentukan Forum Group Discussion melibatkan seluruh partisipasi warga desa, baik ibu rumah tangga, pemuda, orang tua, dan anak-anak. Terdapat 4 FGD yang akan dibentuk, yakni FGD Pertanian, FGD Kewirausahaan, FGD Adat \& Budaya, FGD K3. 


\section{Kampung Eduwisata Hanjeli di Desa Waluran Mandiri Kabupaten Sukabumi \\ Iwan Rizal Setiawan, Indra Griha Tofik Isa, Siska Hestiana, Ashrul Tsani}

\section{FGD Pertanian}

Pada pembentukan kelompok diskusi ini dilakukan pemilihan terhadap orang- orang yang sangat paham tentang materi penanganan lahan pertanian dan sekaligus tentang penanganan penanaman serta pemeliharaan hingga proses panen. Dalam pelaksanaanya FGD ini, diharapkan akan terciptanya pengetahuan di antara masyarakat tentang pertanian khususnya kacang hanjeli, sehingga dengan berbekal pengetahuan pertanian akan memudahkan proses pelaksanaan program desa eduwisata hanjeli di Desa Waluran Mandiri, terutama dalam proses persiapan pada tahun pertama, dan akan menguatkan pelaksanaan pada tahun selanjutnya.

\section{FGD Kewirausahaan}

Segmentasi untuk FGD Kewirausahaan akan melibatkan pemuda dan karang taruna di wilayah Kampung Eduwisata Hanjeli. Program Kerja yang akan dilaksanakan pada FGD ini adalah: (1) Pembuatan konsep strategi pemasaran Kampung Eduwisata; (2) Pembuatan Akun media sosial Instagram, Youtube, web kampung eduwisata; (3) Branding produk olahan hanjeli, sebagai identitas dari hanjeli sehingga memiliki nilai jual yang baik bagi konsumen; (4) Packaging produk olahan hanjeli dengan konsep ergonomis yang memiliki sisi estetika yang baik.

\section{FGD Adat dan Budaya}

FGD Adat dan Budaya memiliki tujuan untuk membuat konsep kesenian yang akan disuguhkan bagi pengunjung, sebagai identitas kearifan budaya lokal. Pihak yang dilibatkan dalam FGD Adat dan Budaya adalah tokoh masyarakat, pelaku seni yang tergabung dalam sanggar seni Dangdawulang serta pemuda dan pemudi. Kesenian utama yang disuguhkan adalah: (1) Tarian Daerah; (2) Dogdog Lojor; (3) Permainan Tradisional Khas Waluran.

\section{FGD K3}

FGD K3 dibentuk sekaligus sebagai wadah pamong masyarakat dan pengunjung yang nantinya menjadi tim pengamanan, kebersihan dan kesehatan baik bagi masyarakat maupun pengunjung. Pembentukan FGD K3 ini menyasar pada pemuda dan karang taruna yang ada di Desa Waluran.

\section{Revitalisasi Lahan Pertanian}

Revitalisasi Lahan Pertanian bertujuan untuk mengembalikan fungsi lahan non produktif, yang sudah lama tidak dimanfaatkan oleh warga menjadi tanah produktif untuk menunjang dalam peningkatan kapasitas produksi tanaman hanjeli. Adapun Langkah yang dilakukan dalam pengambalian lahan adalah sebagai berikut: (1) Pendataan lahan; (2) Penelaahan tingkat pengembalian fungsi; (3) Invetarisasi kebutuhan pengambalian lahan; (4) Pembagian kelompok pengelola lahan; (5) Penentuan jadwal pengelolaan lahan.

\section{Pembuatan Blueprint Kampung Eduwisata Hanjeli Desa Waluran Mandiri}

Hasil dari pelaksanaan Penyuluhan, pembentukan FGD dan revitalisasi lahan pertanian adalah rancangan Blueprint, yang di di dalamnya memuat: (1) Perancangan anggaran infrastruktur; (2) Spot eduwisata 
ABDIMAS: Jurnal Pengabdian Masyarakat Universitas Merdeka Malang

Volume 5, No 3, November 2020: 300-311

yang dihasilkan; (3) Perancangan layout eduwisata (tata letak dan tata ruang); (4) Ragam Kesenian yang dilibatkan; (5) Konsolidasi lahan warga yang digunakan.

\section{Lokakarya Akhir}

Pelaksanaan lokakarya akhir dilaksanakan di Kantor Kecamatan Waluran dengan keterlibatan keseluruhan partisipasi warga dan aparat pemerintahan kecamatan yang terlibat dalam perancangan, pengembangan dan pembentukan Kampung Eduwisata Hanjeli. Pada kegiatan ini akan dilakukan ekspos mengenai hasil kegiatan yang sudah dilaksanakan.

\section{HASIL DAN PEMBAHASAN}

\section{Lokakarya Awal}

Pada rangkaian kegiatan pengabdian yang dilakukan di Desa Waluran Mandiri dengan mengusung program pengembangan desa mitra yang bertujuan untuk membentuk kampung eduwisata hanjeli ditandai dengan dilakukanya kegiatan lokakarya yang bertujuan untuk melakukan sosialisasi terhadap berbagai program yang akan dilakukan, serta merumuskan program berdasarkan kelompok kerja yang ada, sehingga pada kesempatan tersebut seluruh komponen masyarakat yang terlibat dapat memberikan masukan serta pendapat terhadap pelaksanaan ataupunpenambahan program yang dianggap perlu. Adapun peserta yang hadir meliputi sebagai berikut: (1) Unsur aparat kecamatan; (2) Unsur aparat desa; (3) Unsur kepemudaan; (4) Unsur Kelompok Wanita Tani (KWT); (5) Unsur organisasi warga; (6) Unsur PKK.

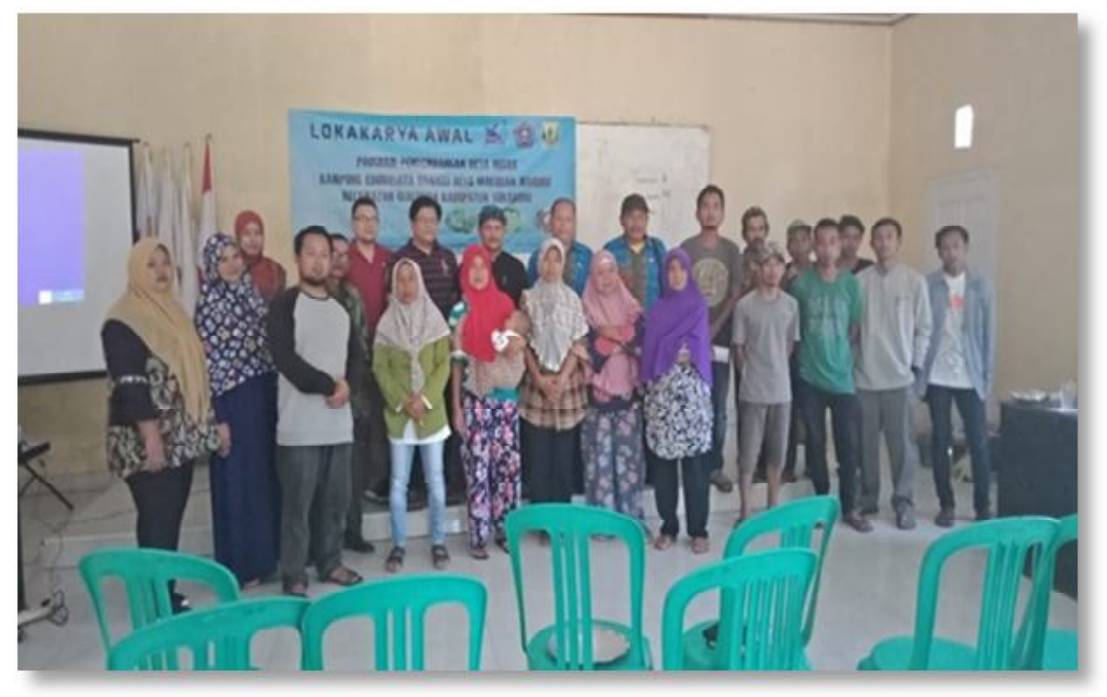

Gambar 5. Pelaksanaan lokakarya awal

\section{Pembentukan FGD}

Pembentukan FGD dimaksudkan sebagai sarana untuk menampung aktifitas dan manajemen dari sub komponen kampung eduwisata hanjeli, adapun FGD yang berhasil terbentuk. 


\section{Kampung Eduwisata Hanjeli di Desa Waluran Mandiri Kabupaten Sukabumi \\ Iwan Rizal Setiawan, Indra Griha Tofik Isa, Siska Hestiana, Ashrul Tsani}

\section{FGD Pertanian}

FGD ini bertanggung jawab terhadap revitalisasi lahan pertanian yang siap ditanami hanjeli, selain itu FGD ini juga bertanggung jawab terhadap proses penanaman, pemeliharaan, serta penyimpanan pasca panen.
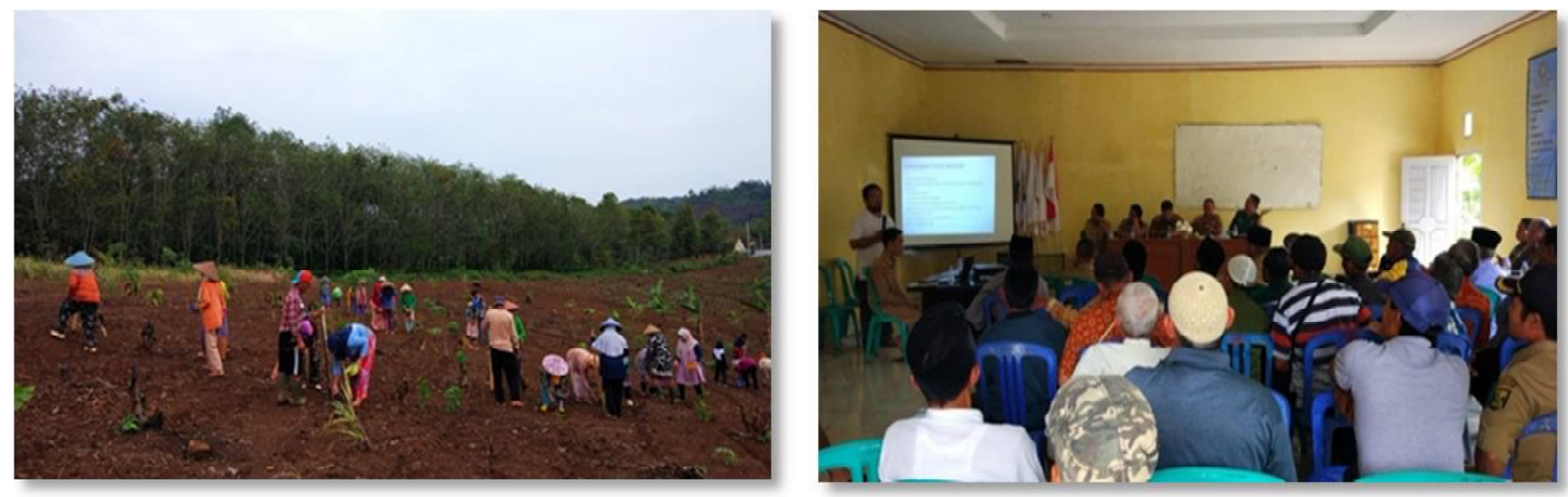

Gambar 6. Penanaman lahan hanjeli

Gambar 7. pembentukan FGD Pertanian

\section{FGD Kewirausahaan}

FGD ini bertanggung jawab terhadap manajemen usaha yang dilakukan oleh masyarakat dalam mengelola komoditas yang berkaitan dengan kampung eduwisata hanjeli. Beberapa program yang dilakukan adalah dengan manajemen usaha pengolahan hanjeli, baik varian penganan berbahan dasar hanjeli, maupun penggunaan limbah hanjeli untuk pembuatan cinderamata atau kerajianan tangan lainnya. Manajemen wirausaha lainya adalah dengan melakukan inovasi dalam penjamuan, serta melakukan beberapa sambutan dengan mengadakan paket-paket eduwisata. Selain itu juga dilakukan pendampingan pembuatan kemasan produk dan media penjualan online yang dapat meningkatkan minat pengunjung secara persuasif (Isa, 2018). Adapun kegiatan terlihat pada Gambar 8 dan Gambar 9.
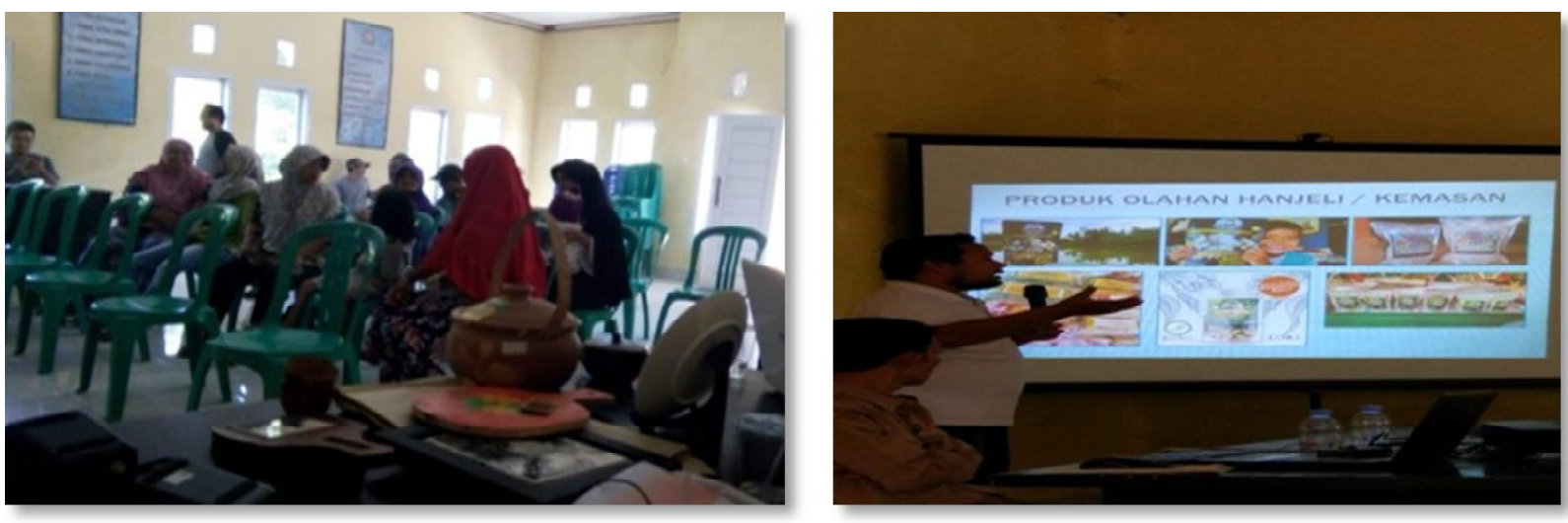

Gambar 8. Pembentukan FGD Kewirausahaan

Gambar 9. Presentasi kewirausahaan 
ABDIMAS: Jurnal Pengabdian Masyarakat Universitas Merdeka Malang Volume 5, No 3, November 2020: 300-311

\section{FGD Seni Adat dan Budaya}

FGD ini bertanggung jawab pada penggalian potensi dan nilai adat serta budaya lokal yang berpotensi untuk dikembangkan dengan proyeksi dapat dipromosikan secara internasional, adapun FGD ini memiliki program dalam melatih para generasi muda dalam membina olah seni, baik dalam bentuk seni bela diri ataupun seni tari dalam rangka menampilkan sajian budaya lokal kepada para tamu yang diharapkan mampu mengangkat seni budaya lokal dan dapat menjasi ciri khas yang ditujukan untuk mengundang kembali kehadiran para wisatawan. Adapun program dari FGD ini adalah melalukan inventarisasi terhadap potensi budaya lokal, kemudian melakukan penggalian dengan pelatihan serta mempelajari seni pertunjukan yang inovatif. Adapun kegiatan terlihat pada Gambar 10 dan Gambar 11.
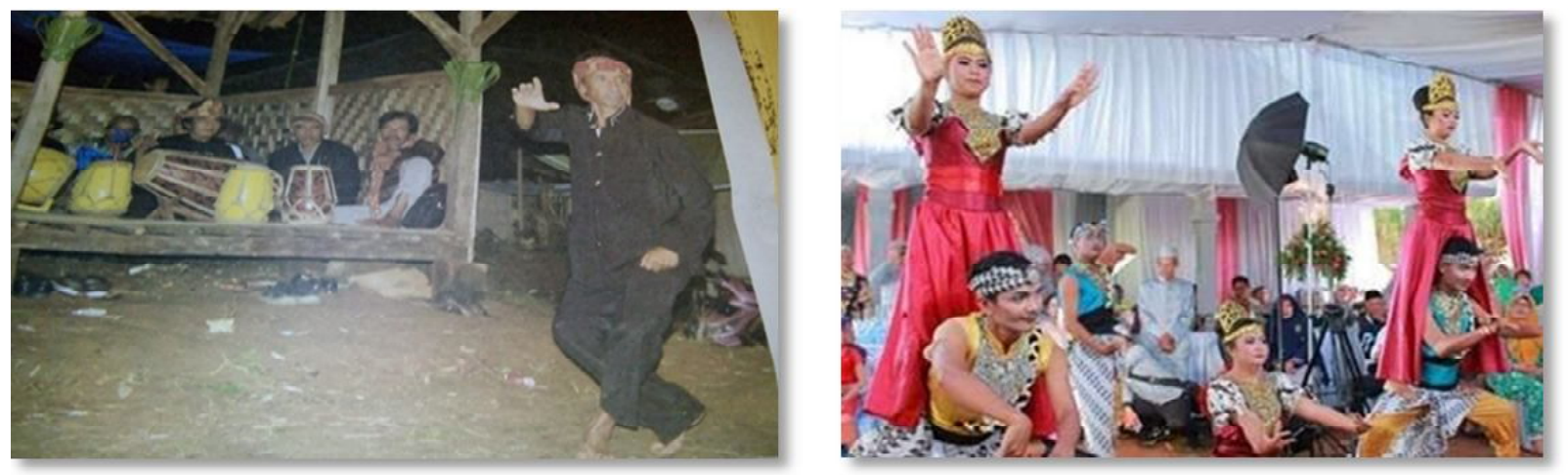

Gambar 10. Seni Pencak Silat Waluran

Gambar 11. Seni Tari Waluran

\section{FGD K3}

FGD ini bertanggung jawab terhadap pelaksanaan Kenyamanan, Kesehatan, dan Ketertiban, program dari FGD ini adalah dengan melakukan pembinaan terhadap kebersihan serta keindahan lingkungan sekitar wilayah Kampung Eduwisata, serta melakukan pelengkapan infrastruktur serta melakukan inovasi dalam menciptakan ruang yang mendukung dalam hal estetika dan keindahan dari sudut pengunjung. Program lainnya dalah dengan memberikan rasa aman serta nyaman bagi pengunjung dengan membuat fasilitas sanitasi serta sarana kesehatan yang diupayakan terus memadai dari waktu ke waktu, serta mendirikan pusat keamanan dan informasi yang dibutuhkan. Beberapa kegiatan yang dilakukan adalah dengan melakukan pelengkapan seperti yang terlihat pada Gambar 12 dan Gambar 13.
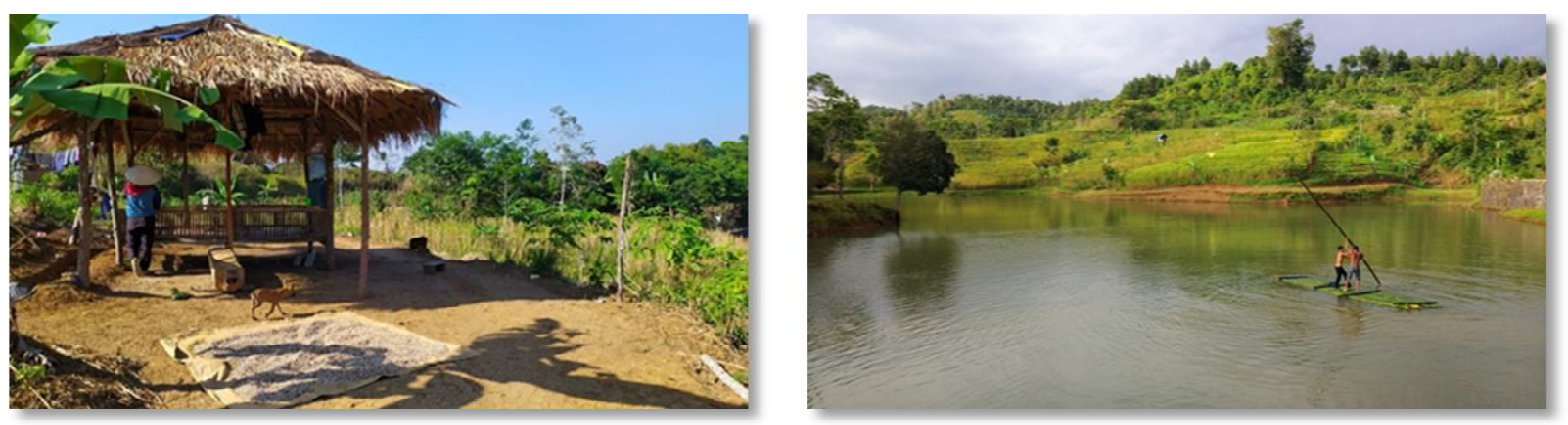

Gambar 12. Spot estetis

Gambar 13. Kebersihan Cekdam (Danau Buatan di sekitar area Kampung Eduwisata) 


\section{Kampung Eduwisata Hanjeli di Desa Waluran Mandiri Kabupaten Sukabumi \\ Iwan Rizal Setiawan, Indra Griha Tofik Isa, Siska Hestiana, Ashrul Tsani}

\section{Spot Edukasi}

Pengertian dari Spot Edukasi adalah dibentuknya ruang-ruang yang dapat dijadikan sebagai bahan pembelajaran ataupun pengetahuan sebagai representasi dari Kampung Eduwisata Hanjeli, adapun spot edukasi ini masih dalam tahap pengembangan dan masih harus banyak mendapatkan bantuan dari berbagai pihak, terutama badan pendidikan dan instansi pemerintah, hal ini disebabkan harus lebih dilengkapinya berbagai literatur serta rujukan dan bahan serta alat peraga.

Kegiatan yang berkaitan dengan Spot Edukasi meliputi pembuatan rumah baca yang akan dilengkapi dengan buku-buku pengetahuan umum dan pengetahuan tentang hanjeli dan konsep desa wisata, spot edukasi berikutnya adalah sentra pengolahan aneka komoditas berbahan hanjeli baik yang bersifat tradisional maupun semi modern, dan spot berikutnya adalah area tumbuh kembang hanjeli secara alami dan secara mandiri, beberapa kegiatan dapat dilihat pada gambar.
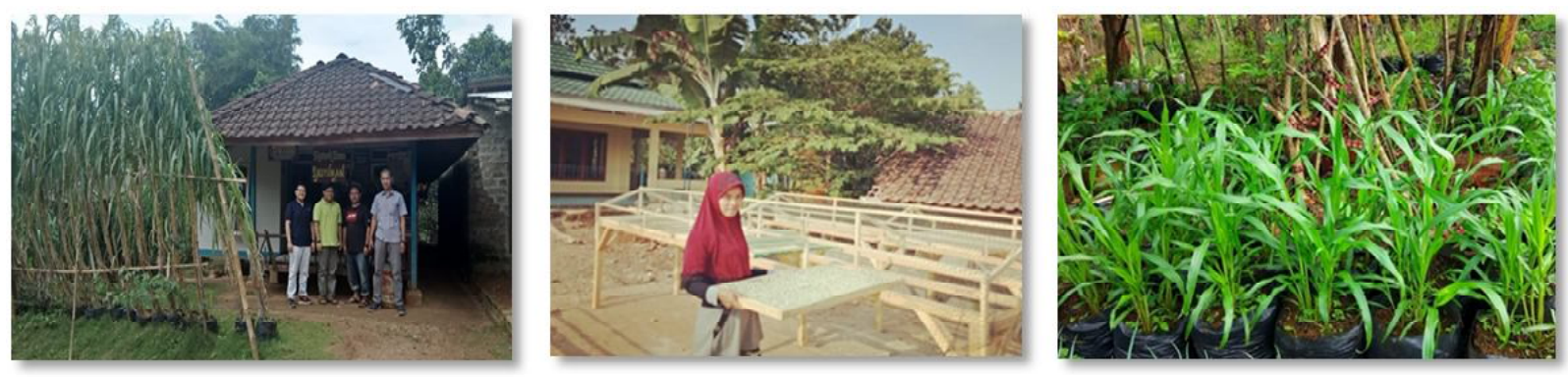

Gambar 14. Spot rumah baca

Gambar 15. Spot produksi penganan

Gambar 16. Spot tanam hanjeli

\section{SIMPULAN DAN SARAN}

\section{Simpulan}

Dalam melaksanakan program pengabdian kepada masyarakat, dengan program kegiatan utama adalah membentuk Kampung Eduwisata Hanjeli Desa Waluran Mandiri banyak sekali ditemukan berbagai permasalahan yang harus dicari solusi dengan cara yang tidak instan. Hal ini berkaitan dengan perilaku masyarakat yang dapat diubah secara perlahan. Sebagai simpulan dapat diuraikan sebagai berikut: (1) Masyarakat sudah mulai menyadari tentang potensi wilayah yang mereka miliki. Hal ini dibuktikan dengan keterlibatan mereka dalam berbagai kegiatan serta keterlibatan unsur masyrakat pada FGD. (2) Masyarakat mulai menyadari tentang potensi tanaman hanjeli yang mereka tanam dapat memberikan keuntungan. Hal ini dibuktikan dengan mulai adanya ketertarikan masyrakat dalam menanam hanjeli, baik secara mandiri ataupun secara berkelompok. (3) Masyarakat mulai tertarik dalam mengolah, dan memasarkan produk olahan berbahan dasar hanjeli. Hal ini dibuktikan dengan mulai dicoba adanya produk perdana sebagai komoditas yang akan terus dikembangkan sehingga dapat meningkatkan pendapatan keluarga, dan sebagaian masyarakat tidak harus menggantungkan hidup keluar wilayah bahkan ke luar negeri. (4) Masyarakat mulai beralih menjadi petani hanjeli, hal ini dibuktikan dengan pembukaan lahan di sekitar wilayah eduwisata sebagai perluasan lahan wisata sekaligus untuk menambah penghasilan dan mulai meninggalkan kebiasaan mereka sebagai penambang emas ilegal 
ABDIMAS: Jurnal Pengabdian Masyarakat Universitas Merdeka Malang

Volume 5, No 3, November 2020: 300-311

\section{Saran}

Sebagai telaahan lanjutan dari pelaksanaan kinerja program PPDM dengan tujuan membangun kampung eduwisata hanjeli, maka dibutuhkan adanya beberapa perbaikan dan perubahan dalam perencanaan selanjutnya, yaitu diantaranya: (1) Melibatkan unsur Pemerintah Daerah secara aktif terutama dari segi regulasi dan dukungan kebijakan, yang diharapkan akan lebih memberikan kekuatan baik terhadap program dan agenda maupun terhadap pembinaan. (2) Melibatkan unsur swasta dalam hal pemanfaatan CSR dari beberapa perusahaan, yang diharapkan dapat memberikan nuansa yang lebih hidup serta akan menambah promosi dari kampung eduwisata Hanjeli Desa Waluran Mandiri. (3) Dilakukan secara terintegrasi dengan beberapa pihak secara menyeluruh yang melibatkan kawasan wisata Geopark Ciletuh, sehingga paket wisata Goepark Ciletuh dapat lebih memberikan variasi dalam penyajian secara mandiri dari masyarakat, khususnya Desa Waluran Mandiri. (4) Diikutsertakan dalam komunitas wilayah dengan mengusung tema yang sama, yaitu Eduwisata. Sehingga diharapkan dapat lebih memberikan wawasan serta kreatifitas antar wilayah masing-masing

\section{UCAPAN TERIMA KASIH}

Tim penulis mengucapkan terima kasih kepada Kementerian Riset, Teknologi dan Pendidikan Tinggi untuk pendanaan Hibah Program Pengabdian Desa Mitra tahun anggaran 2019, juga kepada seluruh masyarakat, perangkat desa dan kecamatan Waluran Kabupaten Sukabumi sehingga pelaksanaan Hibah PPDM untuk tahun anggaran 1 dapat terlaksana dengan baik.

\section{DAFTAR PUSTAKA}

Alamsyah. (2016). Tambang Emas Ilegal di Sukabumi Runtuh, 2 Gurandil Tertimbun. Detiknews. https://news.detik.com/berita/d-3120043/tambang-emas-ilegal-di-sukabumi-runtuh-2gurandil-tertimbun

Azis, B. (2017). Kearifan lokal masyarakat Kampung Wisata Kerajinan Tangan di Dusun Rejoso Kota Batu.. Local Wisdom: Jurnal IImiah Kajian Kearifan Lokal, 9(1). https://doi.org/10.26905/lw.v9i1.1862

Dharmadiatmika, I. M. A. (2019). Desain taman eduwisata berbasis agro. Nature: National Academic Journal of Architecture, 6(1), 73. https://doi.org/10.24252/nature.v6i1a7

Gilang, R. (2018). Polisi Temukan Enam Lubang Tambang Emas Ilegal di Waluran Kabupaten Sukabumi. SUKABUMIUPDATE.com.

https://sukabumiupdate.com/detail/sukabumi/peristiwa/36268-polisi-temukan-enam-lubangtambang-emas-ilegal-di-waluran-kabupaten-sukabumi

Isa, I. G. T. (2018). Kansei engineering approach in software interface design. Jurnal Science Innovare, 1(01), 22-26. https://doi.org/10.33751/jsi.v1i01.680

Isa, I. G. T., Setiawan, I. R., \& Jhoansyah, D. (2019). Potensi industri 'keripik enye' dalam peningkatan kesejahteraan masyarakat Desa Waluran Kabupaten Sukabumi. JMM (Jurnal Masyarakat Mandiri), 3(1), 29-40. https://doi.org/10.31764/jmm.v3i1.920

Madiasworo, T. (2009). Revitalisasi nilai-nilai kearifan lokal Kampung Melayu Semarang. Local Wisdom, $1(1), 10-18$. 


\section{Kampung Eduwisata Hanjeli di Desa Waluran Mandiri Kabupaten Sukabumi}

Iwan Rizal Setiawan, Indra Griha Tofik Isa, Siska Hestiana, Ashrul Tsani

Pramudito, S. (2017). Mengelola kampung dengan kearifan lokal: Belajar dari Kampung Gampingan di Yogyakarta. Jurnal Arsitektur Komposisi, 11(5), 169. https://doi.org/10.24002/jars.v11i5.1291

Solikhah, N., \& Fatimah, T. (2020). Kampung hijau pada kampung kota (studi kasus: Kampung Tanjung Gedong RT.05/ RW.08, Jakarta Barat). Jurnal Baktimas (Jurnal Bakti Masyarakat Indonesia), 3(1), 137-147. https://doi.org/10.24912/jbmi.v3i1.7996

Sudjatnika, T. (2017). Internalization of character educational values of Kampung Adat Cireundeu. 2nd Asian Education Symposium, 2, 44-46. https://doi.org/10.5220/0007298200440046

Susanti, A. (2018). Promosi eduwisata pusat penelitian kopi dan kakao Indonesia di Kabupaten Jember. Mediakom, 1(2), 176-191. https://doi.org/10.32528/mdk.v1i2.1577

Wahyudin, A., Ruminta, R., \& Nursaripah, S. A. (2017). Pertumbuhan dan hasil tanaman jagung (Zea mays L.) toleran herbisida akibat pemberian berbagai dosis herbisida kalium glifosat. Kultivasi, 15(2), 86-91. https://doi.org/10.24198/kultivasi.v15i2.11867 